\title{
One-stage Combined Surgical Treatment of Spinal Deformity and Medulla Spinalis Abnormality
}

\author{
Spinal Deformite ve Medulla Spinalis Anomalilerinin Tek Așamalı Kombine Cerrahisi
}

\author{
(D) Murat Mert ${ }^{1}$, (1) Mete Karatay2 \\ ${ }^{1}$ Yeni Yüzyıl University Faculty of Medicine, Department of Orthopedic Surgery, İstanbul, Turkey \\ ${ }^{2}$ Yeni Yüzyıl University Faculty of Medicine, Department of Neurosurgery, İstanbul, Turkey
}

\begin{abstract}
Introduction: Congenital spinal deformities accompanied by medulla spinalis anomalies are relatively common conditions and can lead to severe complications when left untreated. The conventional treatment approach for severe spine deformity with medulla abnormality is at least a two-stage surgery performed at different times by an orthopaedic and neurosurgeon. However, this might increase hospitalisation time, cost and complication rates. In this study, we aimed to retrospectively evaluate the results of the simultaneous correction of spinal and medulla spinalis deformities in the paediatric population and compare the outcomes with a control group.
\end{abstract}

Methods: The study included 26 patients with spinal deformities such as rigid scoliosis and kyphosis who underwent a deformity correction surgery and 8 patients who underwent a simultaneous correction of spinal and medulla spinalis deformities. Diagnosis, age, additional pathologies and neurological and radiological findings were recorded. Intraoperative and postoperative measures including operation time, intensive care unit (ICU) duration, hospital stay, blood loss, any early and late complications and second revision surgery requirements were evaluated and reported.

Results: The mean operation time was 5.8 (range, 5-8) $\mathrm{h}$ in the study group and $3.4 \mathrm{~h}$ (range, $3-5) \mathrm{h}$ in the control group $(p<0.05)$. The mean blood loss was 1720 (range, 1400-2400) $\mathrm{mL}$ in the study group and 1410 (range, 1200-2000) $\mathrm{mL}$ in the control group. The mean hospitalisation times were 6.4 (range, $5-9$ ) and 4.2 (range, 3-7) days in the study and control groups, respectively $(p<0.05)$.

Conclusion: One-stage orthopaedic and neurosurgical intervention is a safe and convenient approach and does not increase complication risks. Also, the long duration of the surgery does not adversely affect the length of ICU stay and the volume of blood loss.

Keywords: One-stage surgery, spinal deformity, medulla spinalis abnormality, intraspinal abnormality

\section{öZ}

Amaç: Medulla spinalis anomalilerinin eșlik ettiği konjenital spinal deformiteler, oldukça yaygın durumlardır ve tedavi edilmediğinde ciddi komplikasyonlara yol açabilir. Medulla anormalliği ile şiddetli omurga deformitesine geleneksel yaklaşım, farklı zamanlarda ortopedist ve beyin cerrahı tarafından yapılan en az iki aşamalı cerrahidir. Ancak bu yaklaşım hastanede yatış süresini, maliyetini ve komplikasyon oranlarını artııır. Bu çalışmada pediyatrik popülasyonda eşzamanlı olarak düzeltilmiş spinal ve medulla spinalis deformitelerinin sonuçlarını retrospektif olarak değerlendirilmesi ve sonuçların bir kontrol grubuyla karşılaş̦tıııması amaçlanmış̦ır.

Yöntemler: Rijit skolyoz ve kifoz gibi spinal deformiteleri olan 26 hastaya deformite düzeltme ameliyatı uygulandı. Sekiz hastada ise, eş zamanlı spinal ve medulla spinalis deformitelerinin düzeltilmesi yapıldı. Tanı, yaş, ek patolojiler, nörolojik ve radyolojik bulgular kaydedildi. Ameliyat süresi, yoğun bakım ve hastanede kalış süresi, kan kaybı, erken ve geç komplikasyonlar ve ikinci revizyon cerrahisi gereksinimi gibi ameliyat içi ve sonrası değişkenler değerlendirildi.

Bulgular: Ortalama operasyon süresi çalıșma grubunda 5,8 saat (dağııım, 5-8 saat), kontrol grubunda 3,4 saat (dağııım, 3-5 saat) idi $(p<0,05)$. Çalışma grubundaki ortalama kan kaybı $1720 \mathrm{~mL}$ (dağılım, 1400-2400 mL), kontrol grubunda 1410 $\mathrm{mL}$ (dağılım, 1200-2000 mL) idi. Ortalama hastanede yatıs süresi çalışma grubunda 6,4 gün (dağılım, 5-9 gün) ve kontrol grubunda 4,2 gün (dağılım, $3-7$ gün) idi $(p<0,05)$.

Sonuç: Tek aşamalı ortopedik ve nöroşirurjik müdahale güvenli bir yaklaşımdır ve ameliyat süresini, ameliyat sonrasında yoğun bakımda kalış süresini ve kan kaybı miktarını olumsuz etkilememekte ve komplikasyon riskini artırmamaktadır.

Anahtar Kelimeler: Tek aşamalı cerrahi, spinal deformite, medulla spinalis anomalisi, intraspinal anomali 


\section{Introduction}

Congenital spinal deformities accompanied by medulla spinalis anomalies occur in the prenatal period. When left untreated, they can lead to severe complications and even death due to respiratory and cardiovascular system perturbations and other related adverse events (1). Most of the medulla spinalis anomalies develop as a result of a neural tube defect, and the most common ones are tethered cord, syringomyelia, diastematomyelia and myelomeningocele (2).

Since this condition is an early-onset defect and might be diagnosed in the early postnatal period, planning a correction strategy for the future is highly essential. Although the rapid growth phase is initiated, spinal deformities become more severe, unbalanced and rigid, making the correction and fusion surgery more challenging and complicated, particularly in the presence of a medulla spinalis anomaly. A progressive neurologic deficit can develop and prevent ambulation for severe and untreated cases $(3,4)$.

Traditional treatment of severe spine deformity with medulla abnormality is at least a two-stage surgery, which is planned with the collaboration of an orthopaedic and neurosurgeon. However, this approach might affect hospitalisation time, cost and complication rates. And since the patient will go through two operations, hospitalisation and wound healing process, life quality and daily activities would be impaired. There are a limited number of studies on the one-stage combined surgical treatment of spinal deformity and medulla spinalis abnormality corrected simultaneously (5).

This study aimed to retrospectively evaluate the results of simultaneous correction of spinal and medulla spinalis deformities in the paediatric population and compare the outcomes with the data of a control group consisting of spinal deformity cases without medulla spinalis abnormality.

\section{Methods}

This study included 26 patients with spinal deformities such as rigid scoliosis and kyphosis operated for deformity correction and 8 who underwent a simultaneous correction of spinal and medulla spinalis deformities.

All deformity correction surgeries were performed by the same orthopaedic surgeon, and the same senior neurosurgeon attended the cases for the correction of medulla spinalis abnormality. This study was approved by the Ethics Committee of Yeni Yüzyıl University (decision no: 2019/3, date: 04.03.2019), and all patients' parents had signed written consent. The spinal pathologies of the study group consisted of diastematomyelia in three, tethered cord in three and meningomyelocele in two subjects. Both patients and the study group had spinal deformity cases; however, a preoperative magnetic resonance imaging (MRI) study revealed the presence of medulla spinalis abnormality in eight cases. Thus, a one-stage combined surgical treatment procedure was planned for this group and evaluated as the study group in the context of this study.

All cases had whole spine anteroposterior and lateral orthoroentgenogram and spinal MRI before surgery (Figure 1).
Diagnosis, age, additional pathologies and neurological and radiological findings were recorded. All patients were reviewed by a paediatrician for additional pathologies, and surgical approval was obtained from an expert team that evaluated the involvement of any other systems.

Posterior instrumentation and deformity correction using pedicle screws and rods were performed by the orthopaedic surgeon. Neuromonitorisation was used in the whole operation period to prevent neurological damage.

Intraoperative and postoperative measures including operation time, intensive care unit (ICU) duration, hospital stay, blood loss, any early postoperative $X$-rays and late complications and second revision surgery requirements were evaluated and reported (Figure 2).

\section{Statistical Analysis}

SPSS 20.0 statistical software program (IBM, Armonk, NY, USA) was used in all analyses.

\section{Results}

The mean age of the patients ranged from 5 to 15 (mean, 9) years. There
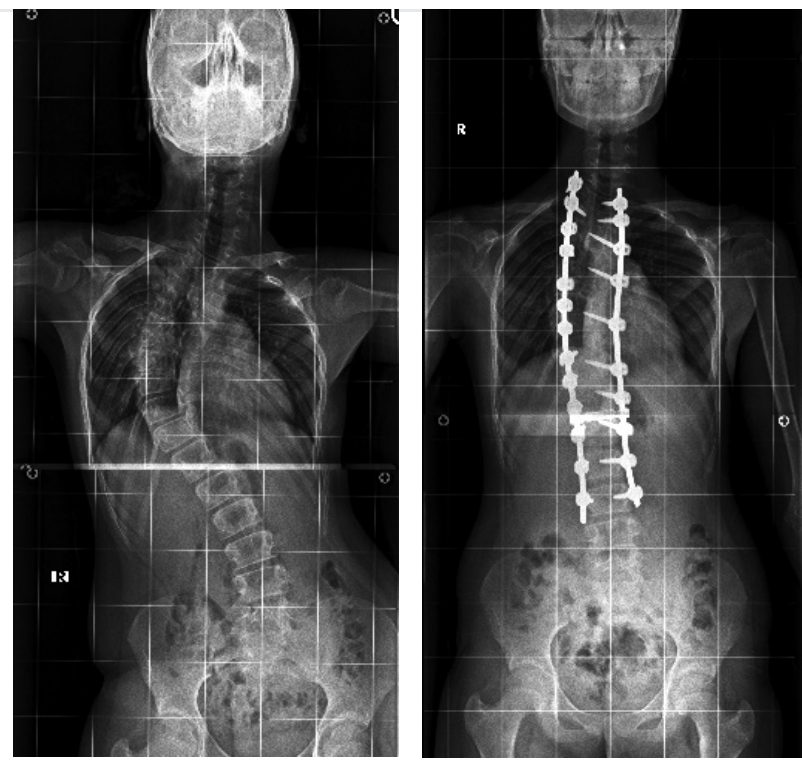

Figure 1. (a) Preoperative axial MRI scan shows diastematomyelia; (b) preoperative coronal MRI scan

MRI: magnetic resonance imaging

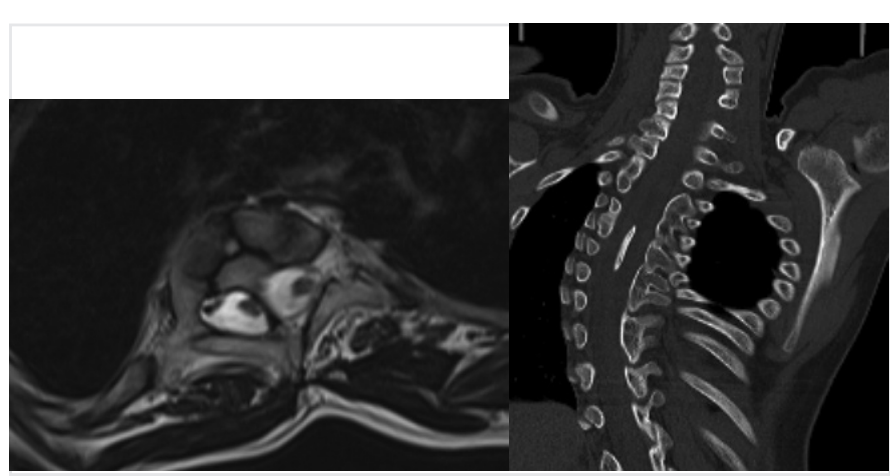

Figure 2. (a) Preoperative and (b) early postoperative X-ray of the same patient 
were 9 female and 25 male patients.

The mean correction ratio of the deformities was $52.4 \%$. The mean operation time was 5.8 (range, 5-8) h in the study group and 3.4 (range, $3-5) \mathrm{h}$ in the control group $(\mathrm{p}<0.05)$. The mean blood losses were 1720 (range, 1400-2400) and 1410 (range, 1200-2000) $\mathrm{mL}$ in the study and control groups, respectively (Table 1).

All patients in the study group stayed in the ICU for at least 1 day, and the patients from the control group were taken into ICU if indicated by the anaesthesiologist. The mean hospitalisation time was 6.4 (range, $5-9$ ) days in the study group and 4.2 (range, 3-7) days in the control group $(\mathrm{p}<0.05)$.

The average follow-up was 3.2 (range, 2-6) years. None of the patients had an impaired neurological status after the surgery. One patient required revision surgery because of a broken rod. Two patients experienced superficial infection, and one patient had a cerebrospinal fluid (CSF) leak, which did not require surgical intervention. One patient had cerebral palsy and was wheelchair-bound, and his or her status did not change following the surgery.

\section{Discussion}

There is no consensus that concomitant spinal deformities and medulla spinalis abnormalities can be corrected in a single session by the cooperation of an orthopaedic and neurosurgeon. Operations by these two medical disciplines in different periods are the conventional approach due to different reasons $(6,7)$. Although some medical centres have a medical team of various disciplines for these cases, some hospitals have experienced on either spinal or neural surgery. Furthermore, there is a common belief that combined surgeries in one session are related to increased intraoperative blood loss, prolonged hospital and ICU length of stay and higher complication rates (8). Although the conventional approach for the correction of both deformities includes at least a two-level correction surgery, difficulties such as longer duration of hospitalisation, the burden of additional surgery, lengthened process of wound healing and medical costs advocate a one-stage surgical

\begin{tabular}{|l|l|l|l|}
\hline Table 1. The comparison data of the study and control groups \\
\hline Variables & $\begin{array}{l}\text { Spinal deformity } \\
\text { and abnormality } \\
\text { (n=8) }\end{array}$ & $\begin{array}{l}\text { Deformity } \\
\text { (n=26) }\end{array}$ & p \\
\hline Age (years) & $9.25 \pm 3.86$ & $9.82 \pm 5.12$ & NS \\
\hline F/M & $2 / 6$ & $7 / 19$ & NS \\
\hline Operation time (h) & $5.8 \pm 2.12$ & $3.4 \pm 1.64$ & $<0.05$ \\
\hline $\begin{array}{l}\text { Intraoperative blood } \\
\text { loss (mL) }\end{array}$ & $1720 \pm 286$ & $1410 \pm 632$ & NS \\
\hline Length of ICU stay & $2.36 \pm 0.67$ & $1.02 \pm 0.34$ & NS \\
\hline $\begin{array}{l}\text { Length of } \\
\text { hospitalisation (days) }\end{array}$ & $6.4 \pm 3.8$ & $4.2 \pm 3.6$ & $<0.05$ \\
\hline Complications & 1 & & \\
\hline Rod break & 0 & 0 & \\
\hline Infection & 1 & 2 & 0 \\
\hline CSF leak & & & \\
\hline F:fent & & & \\
\hline
\end{tabular}

F: female, M: male, ICU: intensive care unit, CSF: cerebrospinal fluid, NS: not significant correction as a more beneficial alternative. Also, multiple surgeries have comorbidities in terms of surgery risks and recurrent anaesthesia and a negative effect on the patient. Since most of the patients in this group are in school age, their academic condition might also be compromised because of the burden of multiple surgeries during the management process.

In our study, we performed a surgical intervention on the patients with concomitant spinal and medulla spinalis defects in the same session, working in harmony with the neurosurgery team. The intraoperative blood loss and the length of ICU stay did not differ between the groups in our study.

The prevalence of additional medulla spinalis deformities alongside a spinal defect varies between $38 \%$ and $43 \%(9,10)$. The variation between the study groups might be a result of the different imaging and diagnostic techniques, and with the implementation of high-resolution MRI, the sensitivity is increased during the time. In the current study, the intraspinal anomalies diagnosed were diastematomyelia, tethered cord, and meningomyelocele, and all were proven by MRI scanning.

In their consecutive series of 24 patients with additional intraspinal pathologies, Murans et al. (11) suggested that an additional neurosurgical procedure combined with fusion surgery did not increase the complication rates compared with fusion surgery alone in their 24-month follow-up period. Their findings reporting a longer operation time is consistent with our data. In their case series of 21 patients, Hamzaoglu et al. (12) suggested that the simultaneous surgical treatment for congenital deformity and intraspinal abnormality is a convenient surgical approach and an efficient alternative and safe treatment option without significant complications.

We did not detect a difference of the age of presentation for both the study and the control groups; thus, we claim that intraspinal defects might not have a presentation and complaint, and all cases planned for spinal deformity surgery should be evaluated using a proper imaging tool to reveal the presence of an additional defect. The decision of a one-stage surgery should be made with a thorough evaluation of each case by expert physicians, and possible complications that might arise from a longer operation and hospitalisation time and increased blood loss should be taken into consideration.

The overall complication rate for the surgical correction of spinal and medulla spinalis abnormalities highly vary, depending on the characterisations of the patient. Implant-related perturbances, infections, correction loss and arthrosis are among the widely observed adverse events in these cases $(13,14)$. Rod break in one patient with meningomyelocele was managed with a reoperation using an additional rod and allograft. CSF leak in one patient with diastematomyelia spontaneously disappeared with conservative treatment. The superficial infection in three patients in the control group was treated with proper antibiotics.

The strengths of our study are that this is a single-centre study, reporting the experience of one orthopaedic surgeon on the correction of spinal defects accompanied by medulla spinalis abnormalities. 
Despite the small number of cases, our data revealing a similar level of intraoperative blood loss and length of hospital stay with a one-stage procedure might suggest the simultaneous correction in one session as a standard approach for appropriate cases.

\section{Conclusion}

We report that a combined one-stage orthopaedic and neurosurgical intervention performed in a single session is a safe and convenient approach and does not increase the risk of complications, and the long duration of the surgery does not adversely affect the length of ICU stay and volume of blood loss during the surgery.

\section{Ethics}

Ethics Committee Approval: This study was approved by the Ethics Committee of Yeni Yüzyıl University (decision no: 2019/3, date: 04.03.2019).

Informed Consent: All patients' parents had signed written consent.

Peer-review: Externally peer-reviewed.

Authorship Contributions: Surgical and Medical Practices - M.M., M.K.; Concept - M.M., M.K.; Design M.M., M.K.; Data Collection or Processing - M.M., M.K.; Analysis or Interpretation - M.M., M.K.; Literature Search M.M., M.K.; Writing - M.M., M.K.

Conflict of Interest: No conflict of interest was declared by the authors.

Financial Disclosure: The authors declared that this study received no financial support.

\section{References}

1. Upasani VV, Ketwaroo PD, Estroff JA, Warf BC, Emans JB, Glotzbecker MP. Prenatal diagnosis and assessment of congenital spinal anomalies: Review for prenatal counseling. World J Orthop 2016; 7: 406-17. eCollection 2016 Jul 18.

2. Netto JMB, Bastos AN, Figueiredo AA, Pérez LM. Spinal dysraphism: a neurosurgical review for the urologist. Rev Urol 2009 Spring; 11: 71-81.
3. Burnei G, Gavriliu S, Vlad C, Georgescu I, Ghita RA, Dughila C, et al. Congenital scoliosis: an up-to-date. J Med Life 2015; 8: 388-97.

4. Cakır CÖ, Caylı SR. Congenital Scoliosis. Turkish Neurosurgery 2014, Vol: 24, Supplement: 1, 29-37

5. Singrakhia M, Malewar N, Deshmukh S, Deshmukh S. Simultaneous Surgical Treatment of Congenital Spinal Deformity Associated with Intraspinal Anomalies. Asian Spine J 2018; 12: 466-75. Epub 2018 Jun 4.

6. Hui H, Tao H-R, Jiang X-F, Fan H-B, Yan M, Luo Z-J. Safety and efficacy of 1-stage surgical treatment of congenital spinal deformity associated with split spinal cord malformation. Spine (Phila Pa 1976) 2012; 37: 2104-13.

7. Chen B, Yuan Z, Chang MS, Huang J-H, Li H, Yang W-Z, et al. Safety and efficacy of one-stage spinal osteotomy for severe and rigid congenital scoliosis associated with split spinal cord malformation. Spine (Phila Pa 1976) 2015; 40: E1005-13.

8. Fehlings MG, Ibrahim GM. Spinal deformity. J Neurosurg Spine 2010; 13: 663-4.

9. Bradford DS, Heithoff KB, Cohen M. Intraspinal abnormalities and congenital spine deformities: a radiographic and MRI study. J Pediatr Orthop 1991; 11 : 36-41.

10. Shen J, Wang Z, Liu J, Xue X, Qiu G. Abnormalities associated with congenital scoliosis: a retrospective study of 226 Chinese surgical cases. Spine (Phila Pa 1976) 2013; 38: 814-8.

11. Murans G, Gustavsson B, Saraste H. One-stage major spine deformity correction surgery: comparison between groups with and without additional neurosurgical intervention, with more than 24 months of follow-up: clinical article. J Neurosurg Spine 2010; 13: 666-71.

12. Hamzaoglu A, Ozturk C, Tezer M, Aydogan M, Sarier M, Talu U. Simultaneous surgical treatment in congenital scoliosis and/or kyphosis associated with intraspinal abnormalities. Spine (Phila Pa 1976) 2007; 32: 2880-4.

13. Mehta VA, Gottfried ON, McGirt MJ, Gokaslan ZL, Ahn ES, Jallo Gl. Safety and efficacy of concurrent pediatric spinal cord untethering and deformity correction. J Spinal Disord Tech 2011; 24: 401-5.

14. Auerbach JD, Lenke LG, Bridwell KH, Sehn JK, Milby AH, Bumpass D, et al. Major complications and comparison between 3-column osteotomy techniques in 105 consecutive spinal deformity procedures. Spine (Phila Pa 1976) 2012; 37: 1198-210. 